\begin{tabular}{l|c|c|}
\hline & International Journal of Current Research in \\
Biosciences and Plant Biology \\
EXCELLENT \\
PUBLISHERS
\end{tabular}

Short Communication

doi: https://doi.org/10.20546/ijcrbp.2018.505.006

\title{
Hormones Affected Cutting Propagation of Cupressus sempervirens 'Stricta'
}

\section{Jing Li ${ }^{1}$, Dejian Zhang ${ }^{1}$, Donglin Zhang' and Yujie Yang ${ }^{1 *}$}

\author{
${ }^{1}$ College of Horticulture and Gardening, Yangtze University, Hubei, 434025, China \\ 2 Department of Horticulture, University of Georgia, Athens, GA, 30602, USA
}

${ }^{*}$ Corresponding author.

\begin{tabular}{ll}
\hline A r ticle In fo & A B S TR A C T \\
\hline $\begin{array}{l}\text { Date of Acceptance: } \\
29 \text { April } 2018\end{array}$ & $\begin{array}{l}\text { Cupressus semperviens 'Stricta' is a member of Cupress family, also called Italian cypress } \\
\text { or Mediterranean cypress, native to the eastern Mediterranean region. It has been } \\
\text { Date of Publication: }\end{array}$ \\
widely cultivated as an ornamental tree all over the world because of its evergreen, \\
drought resistant, heat tolerant, pH adaptable, salt tolerant and narrow-straight-tall \\
habit. To meet the increasing market demands, we carried out the stem cutting \\
propagation in January and treated with different types and various concentration
\end{tabular}

\section{Introduction}

Cupressus semperviens L. 'Stricta' also called Italian cypress or Mediterranean cypress, is a member of Cupress family, and native to the eastern Mediterranean region, is widely cultivated as an ornamental tree all over the world because of its evergreen, drought, heat, and salt tolerance, wide $\mathrm{pH}$ adaptability, and narrow upright habit (Dirr and Heuser, 2012). It is a medium-sized coniferous evergreen tree to $35 \mathrm{~m}$ tall, with a conic crown with level branches and variably loosely hanging branchlets. Italian cypress is very longlived, with some trees reported to be over 1000 
years old. It is also known for its very durable and scented wood, which can be used as doors and furnitures. In cosmetics, it is used as astringent, firing, anti-seborrheic, anti-dandruff, anti-aging and as fragrance (Farjon, 2013). To meet the increasing market demand, we carried out the rooting experiment of adult stem cuttings in January.

\section{Materials and methods}

Plant materials: Hardwood cuttings of Cupressus semperviens L. 'Stricta' were obtained from full flush growth of plants. Cuttings were placed into water immediately after being removed from mother plants. They were trimmed to $10-15 \mathrm{~cm}$ and leaves of the bottom $3-5 \mathrm{~cm}$ were stripped, and then were treated with various concentrations of different rooting hormones.

Experimental treatments: All cuttings were treated with I: Control (no hormone); II: K-IBA at 1,000 ppm; III: K-IBA at 3,000 ppm; IV: K-IBA at 8,000 ppm; V: Hormodin \#1(1,000 ppm); VI: Hormodin \#2 (3,000 ppm); VII: Hormodin \#3 (8,000 ppm); For the application of liquid hormone, cutting were dipped into the concentrations for 10-15seconds, then air dry for at least 10 minutes before placing them into the rooting media. For powdery Hormodin (produced by OHP. Inc.), cuttings were dipped into water first and then dusted with powder.

Treated hardwood cuttings were randomly inserted into 32-cell plug trays filled with the rooting media, with contained Fafard 3L Mix (main ingredients: peat moss and bark) and perlite at $1: 1(V: V)$. The cuttings were thoroughly watered before placing them on the mist bench. The mist bench was covered with $70 \%$ shade cloth and the mist system was set for $20 \mathrm{sec}$ every $20 \mathrm{~min}$ at the first week, then $10 \mathrm{sec}$ every $20 \mathrm{~min}$ thereafter.

Experimental design: A randomized complete block design was used in this experiment with 4 replicates for each treatment and 8 subsamples (cuttings) per replicate per treatment. Rooting percentage, number of roots, average length of roots, and total root length were collected after 6 months. All data were analyzed with SAS and mean separations were run with LSD $(\alpha=0.05)$.

\section{Results and discussion}

Rooting hormone had significant effects on rooting of Italian cypress and all treated cuttings had greater rooting percentages, number of roots, and longer total root length than that of the control after six months (Table 1and Fig. 1). The highest rooting percentage, $56.3 \%$, was obtained under the treatment of KIBA at $3000 \mathrm{mg} / \mathrm{L}$ and both higher and lower concentrations reduced the rooting percentage and rooting quality. Cuttings treated with powdery hormone had rooting percentages from $25.0 \%, 37.5 \%$, and $53.1 \%$ for Hormodin \#1, $\# 2$, \#3, respectively. Hormodin \#3 has the highest rooting percentage in powdery hormone. Comparing the liquid with powdery hormone, the cutting of Italian cypress is sensitive to liquid hormones.

Table 1. Effect of hormone on rooting percentage and quality of Cupressus semperviens L. 'Stricta'

\begin{tabular}{lllll}
\hline Treatment & Rooting $(\%)$ & Number of Roots & Root Length $(\mathbf{c m})$ & Total Root Length $(\mathbf{c m})$ \\
\hline Control & $15.63 \mathrm{C}$ & $11.25 \mathrm{C}$ & $2.96 \mathrm{C}$ & $69.12 \mathrm{C}$ \\
KIBA 1K & $28.13 \mathrm{C}$ & $12.00 \mathrm{C}$ & $5.13 \mathrm{~A}$ & $81.99 \mathrm{~B}$ \\
KIBA 3K & $56.25 \mathrm{~A}$ & $18.50 \mathrm{~B}$ & $5.47 \mathrm{~A}$ & $101.20 \mathrm{~A}$ \\
KIBA 8K & $31.25 \mathrm{BC}$ & $12.75 \mathrm{C}$ & $3.20 \mathrm{C}$ & $56.86 \mathrm{D}$ \\
Horm \#1 & $25.00 \mathrm{C}$ & $10.25 \mathrm{C}$ & $3.11 \mathrm{C}$ & $57.02 \mathrm{D}$ \\
Horm \#2 & $37.50 \mathrm{ABC}$ & $19.50 \mathrm{~B}$ & $4.07 \mathrm{~B}$ & $103.46 \mathrm{~A}$ \\
Horm \#3 & $53.13 \mathrm{AB}$ & $23.75 \mathrm{~A}$ & $4.62 \mathrm{AB}$ & $109.29 \mathrm{~A}$ \\
\hline
\end{tabular}

*Different letters in the same column indicate a significant difference at $\alpha=0.05$ 

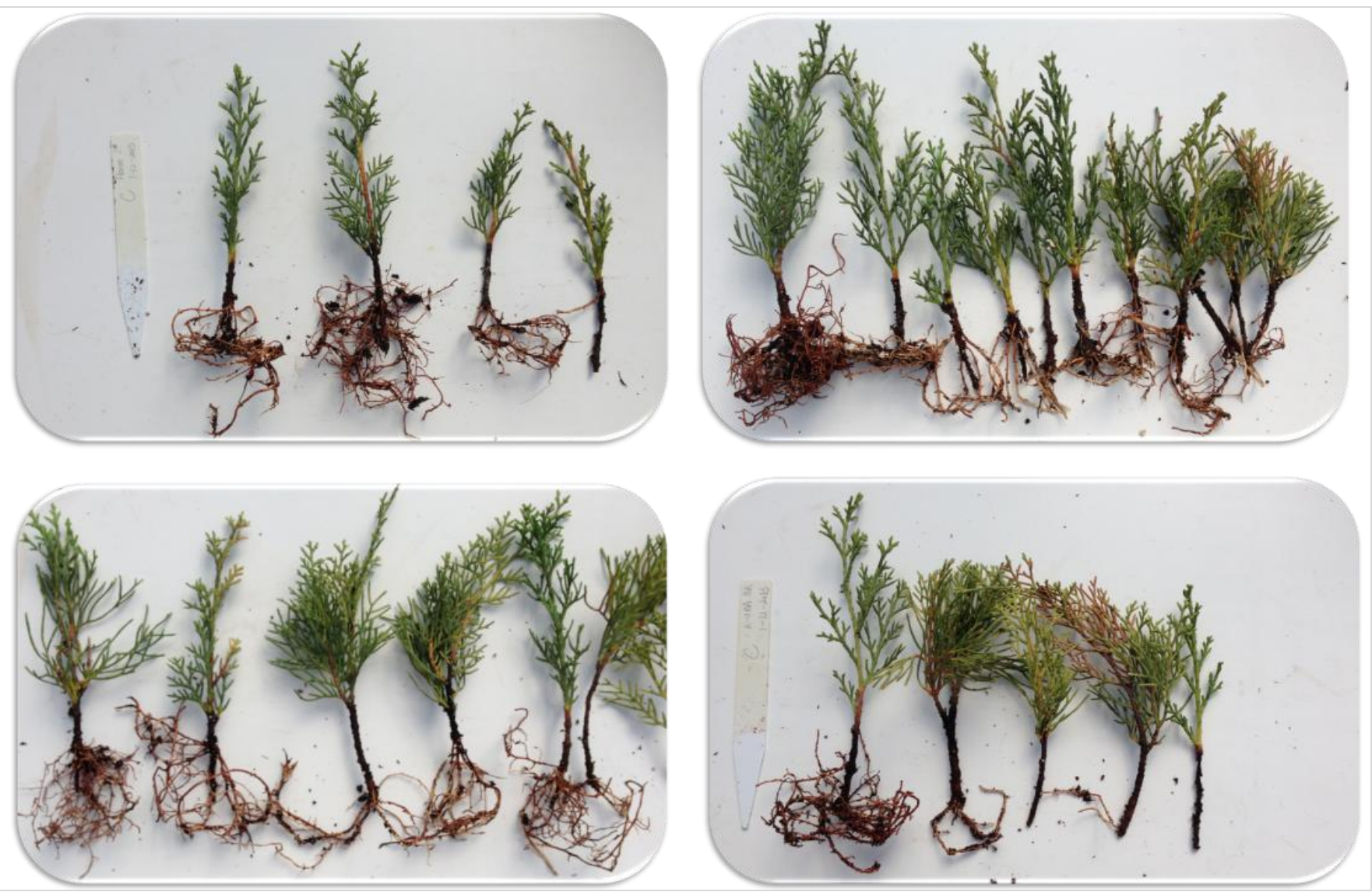

Fig. 1: Rooting of Cupressus semperviens L. 'Stricta' (Italian Cypress) hardwood cuttings under selected treatment (clock wise: Horm\#2, Horm\#3, KIBA 8K, KIBA 3K).

As shown in Table 1, application of rooting hormone did significantly affect the root quality. Hormodin \#3 treatment produced the highest number of roots (23.75) per cutting, which was significant higher than other treatments. KIBA at $3000 \mathrm{mg} / \mathrm{L}$ obtained the longest average root length (5.47), and KIBA at $1000 \mathrm{mg} / \mathrm{L}$ yielded 5.13. Both of them had a significant different with the other treatments. The longest total length of roots, $109.29 \mathrm{~cm}$, was produced using Hormodin \#3. Hormodin \#2 and KIBA at $3000 \mathrm{mg} / \mathrm{L}$ also had significant results than other treatments.

From the above results, growers should apply $8000 \mathrm{mg} / \mathrm{L}$ IBA talc or $3000 \mathrm{mg} / \mathrm{L} \mathrm{KIBA}$ to root adult stem cuttings of Cupressus semperviens 'Stricta'. It is possible to had higher rooting percentage with juvenile stem cuttings and post- chilling period for adult stem cuttings.

\section{Conclusion}

Commercial production of Cupressus semperviens 'Stricta' could be regenerated from hardwood stem cuttings treated by rooting hormones. Hormone types, application methods, and concentrations did significantly affect the rooting of Cupressus semperviens 'Stricta' cuttings. To better rooting percentage and higher quality of liners, powdery Hormodin \#3 and liquid K-IBA at 3,000 ppm is recommended for hardwood cuttings.

\section{Conflict of interest statement}

Authors declare that they have no conflict of interest. 


\section{Acknowledgement}

This work was supported by the Yangtze Initial Fund (801190010133).

\section{References}

Dirr, M.A. and C.W. Heuser. 2012. The reference manual of woody plant propagation: from seed to tissue culture. Varisty Press, Athens, GA.

Farjon, A. 2013 Cupressus sempervirens. The IUCN Red List of Threatened Species. Version 2014.2

\section{How to cite this article:}

Li, J., Zhang, D., Zhang, D., Yang, Y., 2018. Hormones affected cutting propagation of Cupressus sempervirens 'Stricta'. Int. J. Curr. Res. Biosci. Plant Biol. 5(5), 37-40.

doi: https://doi.org/10.20546/ijcrbp.2018.505.006 